\title{
Determination of some chemical compounds of bignay (Antidesma bunius) fruit juice
}

\author{
Gemala HARDINASINTA², Mursalim MURSALIM², Junaedi MUHIDONG², Salengke SALENGKE²* (iD
}

\begin{abstract}
Bignay fruits are produced from wild trees of Antidesma bunius Spreng which can be found in India, Ceylon, and South East Asia countries. Each mature tree can produce hundreds of kilograms of fruits per year, so this fruit has the potential to be used as a raw material in juice and beverage industries. In addition, recent trends in consumer demand indicates that consumers are more inclined to demand products which can provide health benefits. In order to assess the potential of bignay fruit as a raw material for juice production, it is important to determine the health-promoting bioactive compounds contained in fresh bignay fruit juice. Therefore, the objective of this study was to determine the concentration of bioactive compounds in fresh bignay fruit juice. Results obtained from this study showed that bignay fruit juice contained $1202.5 \mathrm{mg} \mathrm{GAE} / 100 \mathrm{~mL}$ of total phenolic, $436.602 \mathrm{mg} / 100 \mathrm{~mL}$ of anthocyanin, $48.931 \mathrm{mg} / 100 \mathrm{~mL}$ of ascorbic acid, and $3.78 \mathrm{mg} / 100 \mathrm{~mL}$ of flavonoid. The scavenging activities obtained from DPPH and ABTS methods were $0.110 \mathrm{mg} / \mathrm{mL}$ and $0.126 \mathrm{mg} / \mathrm{mL}$ respectively. The above results indicate that bignay fruits contain health-promoting chemical compounds and can be used as a natural source of antioxidants.
\end{abstract}

Keywords: Antidesma bunius; color; phenolic compound; ascorbic acid; antioxidant activity.

Practical Application: Bignay fruit was found to contain active compounds with high antioxidant activity so it can provide health benefits. The utilization of this fruit as a raw material for juice industries is viable, especially in its countries of origin.

\section{Introduction}

The utilization of exotic fruits as a raw material in the food industry has become an emerging trend due to their health-promoting functional compounds such as antioxidants. In addition, there is a trend in food industries where synthetic antioxidants were replaced with antioxidants from natural sources (Caleja et al., 2017; Kumar et al., 2015). Among the organic compounds found in fruit that have shown health benefits for humans are vitamins and phenolic compounds such as flavonoids. These compounds have high antioxidant activities and other biological functions. As a source of natural polyphenols and other health-promoting compounds, exotic fruits contain an abundant amount of phenolic acids and flavonoids such as anthocyanin. These compounds have distinct properties such as strong antioxidant activity, anti-inflammatory, and antiproliferative activities which could inhibit cell cancer growth and prevent cardiovascular diseases (Swami et al., 2012; Timmers et al., 2015).

Antidesma bunius is an indigenous species found mainly in the South East Asia region such as Thailand, Philippine, and Indonesia but it can also be found in India and Ceylon. This fruit has different names such as "Maoberry" or "Mao-Luang" in Thailand, "Bignay" in Philippine, and "Buni" in Indonesia. In some countries, this fruit has been consumed in the form of juice, jam, and wine (Chaikham, 2015; Chaikham et al., 2016; Jorjong et al., 2015; Samappito \& Butkhup, 2008).
Studies on bioactive compounds for this fruit have been conducted mainly for bignay from trees grown in northern Thailand. The major flavonoid contents found in those studies were (-)-epicatechin and (+)-catechin (flavan-3-ols), while the major contents of anthocyanin were cyanidin, followed by malvidin, pelargonidin, and delphinidin. Phenolic acids identified in bignay consist of two hydroxybenzoic acids i.e. gallic acid and vanillic acid and five hydroxycinnamic acids i.e. caffeic acid, p-coumaric acid, ferulic acid, sinapinic acid, and cinnamic acid (Butkhup \& Samappito, 2008; Jorjong et al., 2015). There has been no such study conducted for bignay fruits from trees found in Indonesia.

Despite its potential beneficial impacts on health, the intake of bignay fruits in the producing countries such as Indonesia is still very low due to its stone, tart taste, and purple stains when eaten as fresh fruit. Therefore, to increase consumption of this fruit, processing into processed products such as juice and jams need to be done. The increase in consumption of juice and other processed products from fruits with high bioactive compounds can help meet the recommended daily intake for fruits and provide additional health benefits. For example, Asgary et al. (2014) reported that consumption of high-flavonoid sweetie juice provided a higher reduction of Diastolic Blood Pressure (BDP) compared to the consumption of low-flavonoid sweetie juice. The objectives of this study were to determine total phenolic, total monomeric anthocyanin, total flavonoid, and vitamin C 
contents of bignay juice and to determine the antioxidant activity of fresh bignay fruit juice. Besides, the color and $\mathrm{pH}$ of fresh bignay fruit juice were also measured. This is important since the color of a fruit can be used as an indicator to predict the chemical compounds contained in the fruit. Several chemical compounds that have been proven to provide a beneficial impact on health also serve as a color pigment. Anthocyanin is used as a source for the blue-purple pigment, lycopene for red pigment, and $\beta$-carotene for orange pigment (Jamal et al., 2017).

\section{Materials and methods}

\subsection{Sample preparation}

Bignay fruits were bought from a local market in Makassar, South Sulawesi, Indonesia. The fruits were washed and sorted based on the maturity level. The ripe fruits (purple blackish color) were chosen and processed into juice using a commercial juicer (Philips HR1832). The juice obtained was filtered through cheesecloth to separate the pulp and the fresh juice obtained was poured into a $500 \mathrm{~mL}$ PTFE bottle and stored in a freezer maintained at $-18^{\circ} \mathrm{C}$ until used.

\subsection{Determination of $p H$, Total Soluble Solids (TSS), and color}

The $\mathrm{pH}$ measurement was carried out using a $\mathrm{pH}$ meter (LAQUAtwin $\mathrm{pH}-11$, Horiba Scientific, Japan) calibrated with buffer solutions of $\mathrm{pH} 7.0$ and 4.0. Total soluble solid (TSS, expressed in ${ }^{\circ} \mathrm{Brix}$ ) was measured using a digital refractometer (HI 96801, Hanna Instruments, Rhode Island, USA) calibrated with distilled water. The color of the juice was determined using a colorimeter (CS-10 Colorimeter, Hangzhou CHN Spec Technology, China). Color parameters of the samples were determined based on CIE $\mathrm{L}^{*} \mathrm{a}^{*} \mathrm{~b}^{*}$ parameters, where $\mathrm{L}^{*}$ represents the lightness with value ranged from $0-100$ (black-white axis), $\mathrm{a}^{\star}$ represents the green-red color with value ranged from -60 to +60 (green-red axis), and $b^{\star}$ represents the blue-yellow color with ranged of -60 to +60 (blue-yellow axis).

\subsection{Total phenolic content}

Total phenolic measurement was conducted according to the Folin Ciocalteu method described in Tezcan et al. (2009) with some modification. The stock solution was made by diluting $0.1 \mathrm{~mL}$ of bignay fruit juice in $10 \mathrm{~mL}$ of methanol:water $(6: 4 \mathrm{v} / \mathrm{v})$ solvent. The determination of phenolic compounds was performed as follows. $0.5 \mathrm{~mL}$ of stock solution was mixed with $1.5 \mathrm{~mL}$ of Folin Ciocalteu reagent (7.5\%) and $1.2 \mathrm{~mL}$ of $\mathrm{Na}_{2} \mathrm{CO}_{3}(7.5 \%)$ and then topped with distilled water to reach a total volume of $5 \mathrm{~mL}$. The mixture was kept for 90 minutes at room temperature before the measurement of absorbance was conducted at $760 \mathrm{~nm}$ using UV-Vis Spectrophotometer (UV-1800, Shimadzu, Japan). The results were expressed as gallic acid equivalent (mg GAE/100 mL juice) using calibration curved of gallic acid from 2-10 ppm.

\subsection{Total anthocyanin content}

The total monomeric anthocyanin assay was determined using the $\mathrm{pH}$ differential method as described in the literature
(Jiang et al., 2013). Briefly, two dilutions of samples were prepared by adding $50 \mu \mathrm{L}$ of samples with $4950 \mu \mathrm{L}$ of potassium chloride $(0.025 \mathrm{M})$ buffer $\mathrm{pH} 1.0$ and the other with sodium acetate $(0.4 \mathrm{M})$ buffer $\mathrm{pH}$ 4.5. The absorbance of each sample was measured after 20 minutes at wavelengths of 520 and $700 \mathrm{~nm}$. Total anthocyanin content was determined based on the absorbance value obtained from Equation 1.

$A=\left(A_{520}-A_{700}\right)_{p H 1,0}-\left(A_{520}-A_{700}\right)_{p H 4,5}$

where $A_{520}$ is the absorbance at the $520 \mathrm{~nm}$ wavelength, and $\mathrm{A}_{700}$ is the absorbance at the wavelength of $700 \mathrm{~nm}$. Total anthocyanin was represented as cyanidin-3-glucoside and calculated using Equation 2:

Anthocyanin $\left(\frac{m g}{L}\right)=\frac{A \times M W \times D F \times 10^{3}}{\varepsilon \times l}$

where $\mathrm{A}$ is the absorbance value, $\mathrm{MW}$ is the molecular weight of standard $(445.2 \mathrm{~g} / \mathrm{mol}), \mathrm{DF}$ is the dilution factor, $\varepsilon$ is the molar absorption capacity $(29,600 \mathrm{l} / \mathrm{mol} . \mathrm{cm})$, and $\mathrm{l}$ is the cuvette length $(1 \mathrm{~cm})$.

\subsection{Ascorbic acid content}

The ascorbic acid content was measured using Ultra-Fast Liquid Chromatography (UFLC) based on the method represented in literature (Mercali et al., 2014) with some modifications. The preparation of the stock sample was carried out by adding $1.5 \mathrm{~mL}$ of sample into $7.5 \mathrm{~mL}$ of meta-phosphoric acid solution (4.5\%). The mixture was filtered through a syringe filter of $0.45 \mu \mathrm{m}$, and $40 \mu \mathrm{L}$ was injected into the UFLC system (Prominence UFLC, Shimadzu, Japan).

The UFLC conditions were described as follows: The column used was a reverse $C_{18}$ (Shimadzu, Japan) and the separation was carried out under isocratic condition using a mobile phase of $\mathrm{KH}_{2} \mathrm{PO}_{4}(5 \%)$. The eluent flow rate was $0.7 \mathrm{~mL} / \mathrm{min}$ and the column temperature was set at $25^{\circ} \mathrm{C}$. The absorbance was measured at $254 \mathrm{~nm}$ and pure ascorbic acid was used as standard.

\subsection{Total flavonoid content}

Total flavonoid content was measured using Thin Layer Chromatography (TLC) based on the method used by several researchers (Altemimi et al., 2015) with some modification. A $20 \times 20 \mathrm{~cm}$ TLC silica gel $60 \mathrm{~F}_{254}$ plates (Merck, Germany) were divided into four equal pieces $(5 \times 20 \mathrm{~cm})$ and then placed into an oven at $110^{\circ} \mathrm{C}$ for $20-30 \mathrm{~min}$ prior to use. The separation was carried out using the mixture of ethyl acetate: formic acid: water $(10: 2: 3 \mathrm{v} / \mathrm{v})$ as the solvent. $10 \mathrm{~mL}$ of solvents were saturated inside the chromatography chamber for 30-40 min before used. For the measurement, $2 \mu \mathrm{L}$ of samples and standards were dotted on the TLC plate with a $1 \mathrm{~cm}$ gap between each dotted sample. The plate was placed inside the chamber until the separation process was completed. The determination of flavonoid content was performed by densitometer (Camag TLC scanner 3, Switzerland) at a wavelength of $254 \mathrm{~nm}$ and the concentration was expressed as $\mathrm{mg}$ rutin/100 $\mathrm{mL}$ of juice. 


\subsection{Antioxidant activity}

\section{2,2 Diphenyl-1-picrylhydrazyl (DPPH) assay}

The scavenging activity of DPPH radical was measured based on the method described in Kenny et al. (2013) with modifications. DPPH solution was made by diluting $8 \mathrm{mg}$ of DPPH (Sigma-Aldrich) with $50 \mathrm{~mL}$ of methanol. A stock solution of the sample was prepared by dilution of $5 \mathrm{mg}$ juice in $5 \mathrm{~mL}$ of $100 \%$ methanol. Five different concentrations (75-375 ppm) of each sample were performed by pipetting $15,30,45,60$, and $75 \mu \mathrm{L}$ of the stock sample across the 96 -well plate. A methanol blank was also used as a negative control. The DPPH solution $(75 \mu \mathrm{L})$ was added to the plate and then topped with methanol to the final volume of $200 \mu \mathrm{L}$. The mixture was stored in the dark for 30 minutes at room temperature before its absorbance at $515 \mathrm{~nm}$ was measured using ELISA plate reader (ELx808 BioTek, Vermont, USA). The results were expressed in $\mathrm{IC}_{50}$ scavenging activity.

\section{2,20-azino-bis (3-ethylbenzthiazonline-6-sulfonic acid) (ABTS) assay}

The determination of ABTS scavenging was carried out according to the method described in (Jorjong et al., 2015) with some modification. The stock solution of the ABTS reagent was prepared by mixing $7.4 \mathrm{mM}$ ABTS solution and $2.6 \mathrm{mM}$ potassium persulfate solution with the ratio of $1: 1(\mathrm{v} / \mathrm{v})$. The ABTS solution was made by diluting $0.018 \mathrm{~g}$ of ABTS with $5 \mathrm{~mL}$ of methanol, while the potassium persulfate solution was prepared by diluting $3.6 \mathrm{mg}$ of potassium persulfate with $5 \mathrm{~mL}$ of methanol. The mixture of ABTS and potassium persulfate solutions was topped with methanol to reach the total volume of $25 \mathrm{~mL}$. The solution was then incubated in the dark for 12-16 hours.

The stock solution of the sample that had been prepared for the measurement of scavenging activity using the DPPH method was also used for this ABTS scavenging test. The varying volume of the stock solution was pipetted into a well plate to form five different concentrations. Methanol was used as the negative blank. ABTS stock solution was added to the plate with a volume of $125 \mu \mathrm{L}$ and topped with methanol to the final volume of $200 \mu \mathrm{L}$. The mixture was left in the dark for 30 minutes at room temperature before absorbance measurement was conducted at $650 \mathrm{~nm}$ using ELISA plate reader.

All the measurements were conducted in triplicates. The IC50 values and statistical analysis were determined using GraphPad Prism 8.0. All data except antioxidant activity will be express in mean \pm standard deviation value.

\section{Results and discussions}

\subsection{Physical characteristics of bignay juice}

The physical characteristics measured were color parameters of fresh juice, $\mathrm{pH}$, and total soluble solid content, and the results are given in Table 1 . From the color parameter data, bignay fruit juice provided a dark-colored liquid as shown by the low Lightness and Chroma value. Dark-colored fruits are generally known as a potential source for anthocyanin (Wu et al., 2012).
The $\mathrm{pH}$ value obtained indicates that bignay fruit juice can be categorized as a high acid food $(\mathrm{pH}<3.6)$. The $\mathrm{pH}$ of foods and beverages is an important factor that affects their shelf life and processing condition. The lower $\mathrm{pH}$ level of the bignay fruit juice may permit short pasteurization time at relatively moderate temperatures since pathogenic bacteria do not grow at low $\mathrm{pH}$ (Achir et al., 2016; Branco et al., 2016; Park \& Kang, 2013). In addition, $\mathrm{pH}$ also influences the stability of compounds in the food product. Anthocyanin has been reported to be susceptible toward $\mathrm{pH}$, where acidic condition provides higher stability of this compound (Fredes et al., 2018; Jiang et al., 2015). The $\mathrm{pH}$ value obtained in this study (3.45) was equivalent to the $\mathrm{pH}$ level of Phuchong cultivars as reported in Butkhup \& Samappito (2008). The $\mathrm{pH}$ of bignay fruit and its products that have been reported in literature ranged from 3.40 to 3.50 (Butkhup \& Samappito, 2008; Chaikham, 2015; Chaikham et al., 2016; Sripakdee et al., 2015).

The total soluble solid (TSS) of fresh bignay juice obtained in this study $\left(14.67^{\circ} \mathrm{Bx}\right)$ was comparable with those reported in Butkhup \& Samappito (2008) for Sangkrow No.2 cultivar $\left(14.50{ }^{\circ} \mathrm{Bx}\right)$ and Phuchong cultivar $\left(14.80^{\circ} \mathrm{Bx}\right)$. Higher TSS value $\left(16.50^{\circ} \mathrm{Bx}\right)$ was reported by Sripakdee et al. (2015) and Butkhup \& Samappito (2008) for Sangkrow No. 5 cultivar, while lower values (12.77 and $12.35^{\circ} \mathrm{Bx}$ ) were respectively reported in Chaikham et al. (2016) and Butkhup \& Samappito (2008) for Sangkrow No.4 cultivar. In terms of $\mathrm{pH}$ value and total soluble solid, bignay juice originated from Indonesia has similar characteristics to the Phuchong cultivars grown in Thailand.

\subsection{Chemical characteristics of bignay juice}

Results of chemical analysis of bignay juice were presented in Table 2. Total phenolic (TP) content of bignay juice used in this study was much higher $(1202.5 \mathrm{mg} / 100 \mathrm{~mL})$ than the value reported (274.65 mg GAE/100 mL) in Chaikham et al. (2016). A lower amount of TP was also reported in several studies (Chaikham, 2015; Jorjong et al., 2015; Sripakdee et al., 2015). These authors reported TP contents of $390.67 \mathrm{mg} / 100 \mathrm{~mL}$, $345.68 \mathrm{mg}$ GAE/100 g dry weight (DW), and $337.52 \mathrm{mg}$ GAE/100 mL respectively. On the other hand, higher TP content (1978.38 mg/100 g DW) was reported in the crude extract by Barcelo et al. (2016). It is important to note that the TP content found in this study was within the range reported by Butkhup \& Samappito (2008) who reported the TP values

Table 1. Physical characteristics of bignay juice.

\begin{tabular}{lc}
\hline \multirow{2}{*}{ Parameter } & Value \\
\cline { 2 - 2 } Color: & Mean $\pm \mathrm{SD}$ \\
$\mathrm{L}^{*}$ & $25.885 \pm 0.035$ \\
$\mathrm{a}^{*}$ & $-0.470 \pm 0.010$ \\
$\mathrm{~b}^{*}$ & $1.460 \pm 0.370$ \\
Chroma $\left(\mathrm{C}^{*}\right)$ & $1.537 \pm 0.354$ \\
Hue angle $\left({ }^{\circ} \mathrm{h}\right)$ & $-1.243 \pm 0.071$ \\
$\mathrm{pH}$ & $3.453 \pm 0.031$ \\
Total soluble solids $\left({ }^{\circ} \mathrm{Bx}\right)$ & $14.667 \pm 0.094$ \\
\hline
\end{tabular}


of 8.37-13.56 mg GAE/g DW (837-1356 mg GAE/100 mL). The addition of water during the extraction process might become a contributing factor that caused the TP content of bignay juice was lower in several studies (Chaikham, 2015; Jorjong et al., 2015). It is important to note that in our study, the extraction of juice from bignay fruits was accomplished without the addition of water.

The total phenolic content of bignay juice found in this study is higher than those of other juices such as pomegranate juice (230.86 mg GAE/100 mL) (Yildiz et al., 2009), grape juice (2135-2647 mg/L) (Padilha et al., 2017), and mulberry juice (266.8 mg GAE/100 g DW) (Kamiloglu et al., 2013a). A high amount of TP found in bignay juice can be explained by the major phenolic acid in this fruit, which is gallic acid and vanillic acid (Butkhup \& Samappito, 2008; Jorjong et al., 2015). In comparison, the major phenolic acid reported in mulberry fruit was chlorogenic (Kamiloglu et al., 2013b).

As mentioned before, the dark-colored fruit potentially contains high anthocyanin content. This was in agreement with the result obtained in this study, where the anthocyanin content of bignay juice was $426.602 \mathrm{mg} / 100 \mathrm{~mL}$ of juice. The anthocyanin content found was significantly higher than those reported previously by Chaikham (2015) $(59.46 \mathrm{mg} / 100 \mathrm{~mL})$ and Chaikham et al. (2016) (44.32 mg/100 mL) for bignay juice, Barcelo et al. (2016) (131.42 mg/100 g DW for extract), and Butkhup \& Samappito (2008) (141.94 mg/100 g DW for fruit). The varying level of anthocyanin can be due to the difference in maturity or ripeness during harvest, considering that at the earlier stage of maturity bignay fruits display bright red-color, while at the later stage the color shifts to dark-purple.

Vitamin C content of bignay juice is represented in ascorbic acid equivalent. The result obtained in this study ( $48.93 \mathrm{mg} / 100 \mathrm{~mL}$ ) is higher than the ascorbic acid content of bignay juice reported by Chaikham (2015) and Chaikham et al. (2016). In these two studies, the vitamin C contents reported were $19.05 \mathrm{mg} / 100 \mathrm{~mL}$ and $26.14 \mathrm{mg} / 100 \mathrm{~mL}$ respectively. The vitamin $\mathrm{C}$ content of bignay juice found in this study was comparable to the ascorbic acid content of orange juice (ranged from 249.81-612.75 mg/L) (Sánchez-Moreno et al., 2003). Therefore, this result indicates that bignay juice could become a potential source of vitamin C

Table 2. Bioactive compounds in bignay juice.

\begin{tabular}{lc}
\hline \multicolumn{1}{c}{ Compounds } & Value \\
\cline { 2 - 2 } & \multicolumn{1}{c}{ Mean \pm SD } \\
\hline Total Phenolic $(\mathrm{mg} / 100 \mathrm{~mL})^{\mathrm{a}}$ & $1202.500 \pm 0.001$ \\
Total Monomeric Anthocyanin $(\mathrm{mg} / 100 \mathrm{~mL})^{\mathrm{b}}$ & $426.602 \pm 3.723$ \\
Vitamin C $(\mathrm{mg} / 100 \mathrm{~mL})^{\mathrm{c}}$ & $48.931 \pm 0.001$ \\
Total Flavonoid $(\mathrm{mg} / 100 \mathrm{~mL})^{\mathrm{d}}$ & $3.78 \pm 2.114$ \\
Antioxidant activity: & 0.110 \\
DPPH method-IC50 $(\mathrm{mg} / \mathrm{mL})$ & 0.126 \\
ABTS method-IC50 $(\mathrm{mg} / \mathrm{mL})$ & \\
\hline
\end{tabular}

${ }^{\text {a } g a l l i c}$ acid equivalent; ${ }^{\mathrm{b}}$ cyanidin-3-glucoside equivalent; 'ascorbic acid equivalent; ${ }^{\mathrm{d}}$ rutin equivalent. for the human diet and can be used as a substitute for orange juice which can be expensive in certain regions.

In contrary to other compounds reported previously, the flavonoid content of bignay juice found in this study $(3.78 \mathrm{mg} / 100 \mathrm{~mL})$ was significantly lower than those reported by others. A study conducted by Butkhup \& Samappito (2008) reported that the amount of rutin in bignay fruit ranged from $16.61-25.54 \mathrm{mg} / 100 \mathrm{~g}$ fruit weight (FW) and the total flavonoid content was in the range of $120.39-397.90 \mathrm{mg} / 100 \mathrm{~g}$ FW. A study by Jorjong et al. (2015) on bignay cultivars from Thailand reported total flavonoid content ranged from $138.60-289.60 \mathrm{mg}$ catechin (CE)/100 g DW. The significant difference in the total flavonoid content found in this study and those reported by others might be attributed to the difference in the type of varieties and growing conditions. Another contributing factor might be the analytical method, mainly the use of different types of compounds as the equivalent standard.

The antioxidant activity of bignay juice (Figure 1) was measured by DPPH and ABTS method. The principal of both methods was based on the reaction between hydrogen donor antioxidants with free radicals that would result in a discoloration of those radical substances (Pisoschi \& Negulescu, 2011). The antioxidant activity of bignay juice was expressed by the half-maximum inhibitory concentration (IC50) of a sample that measures the concentration needed by a sample to inhibit $50 \%$ of the free radical reaction. The IC50 found in this study for bignay juice was $0.11 \mathrm{mg} / \mathrm{mL}$ for the DPPH method and $0.126 \mathrm{mg} / \mathrm{mL}$ for the ABTS method. The value of IC50 has a negative correlation with the antioxidant activity, which means that a smaller IC50 value corresponded to higher antioxidant activity. Previous research evaluating the antioxidant activity of bignay fruit grown in Manipur, India, exhibited lower antioxidant activity with an IC50 value of $1717 \mu \mathrm{g} / \mathrm{mL}(1.717 \mathrm{mg} / \mathrm{mL})$ (Khomdram \& Devi, 2010). However, relatively similar value have been reported with other types of fruit such as Litchi chinensis fruit pulp extract $(0.102 \mathrm{mg} / \mathrm{mL})$ (Prakash et al., 2011), Radix Angelicae Sinensis extracted by ethyl acetate $(0.13 \mathrm{mg} / \mathrm{mL})$ (Li et al., 2009), Angelicae Sinensis extract $(0.093 \mathrm{mg} / \mathrm{mL}$ by water extraction and $0.15 \mathrm{mg} / \mathrm{mL}$ by $95 \%$ ethanol extraction). The antioxidant activity of bignay juice found in this study is relatively similar to the antioxidant activity of Radix Angelicae Sinensis extract which many consider

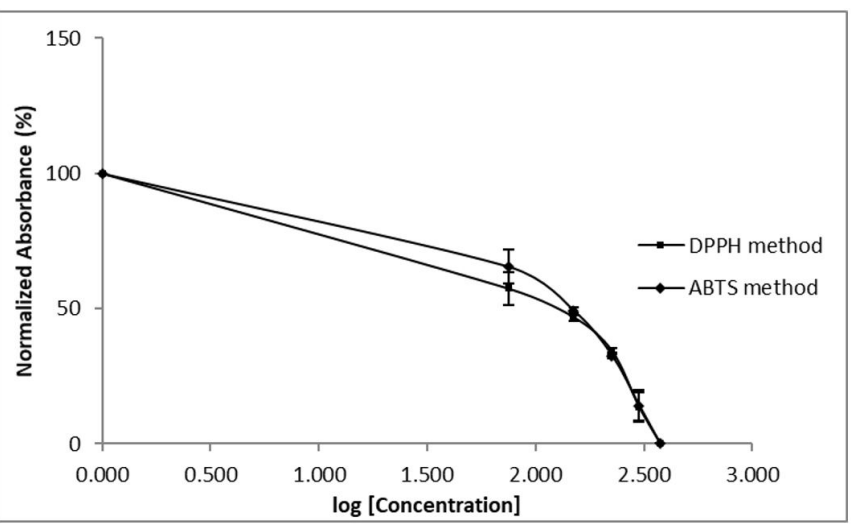

Figure 1. Radical scavenging activity of bignay fruit with DPPH and ABTS methods. 
as a superior traditional Chinese medicine with various health benefits such as promoting the blood circulations, regulating menstruations, and relieving pain (Li et al., 2009).

\section{Conclusions}

Bignay juice was found to contain high amounts of total phenolic, anthocyanin, and vitamin $\mathrm{C}$ and has relatively high antioxidant activity. Therefore, bignay fruit can be used as a natural source of antioxidant and as a potential source of raw material for juice processing industries.

\section{Acknowledgements}

This research was funded by the Indonesian Ministry of Research, Technology, and Higher Education under the PMDSU Program managed by the Directorate of Human Resources Qualification. Salaries and research support were provided by Hasanuddin University.

\section{References}

Achir, N., Dhuique-mayer, C., Hadjal, T., Madani, K., Pain, J., \& Dornier, M. (2016). Pasteurization of citrus juices with ohmic heating to preserve the carotenoid profile. Innovative Food Science \& Emerging Technologies, 33, 397-404. http://dx.doi. org/10.1016/j.ifset.2015.11.002.

Altemimi, A., Watson, D. G., Kinsel, M., \& Lightfoot, D. A. (2015). Simultaneous extraction, optimization, and analysis of flavonoids and polyphenols from peach and pumpkin extracts using a TLCdensitometric method. Chemistry Central Journal, 9(1), 39. http:// dx.doi.org/10.1186/s13065-015-0113-4. PMid:26106445.

Asgary, S., Sahebkar, A., Afshani, M. R., Keshvari, M., Haghjooyjavanmard, S., \& Rafieian-Kopaei, M. (2014). Clinical evaluation of blood pressure lowering, endothelial function improving, hypolipidemic and antiinflammatory effects of pomegranate juice in hypertensive subjects. Phytotherapy Research, 28(2), 193-199. http://dx.doi.org/10.1002/ ptr.4977. PMid:23519910.

Barcelo, J. M., Nullar, A. R. M., Caranto, J. K. P., \& Abigail, M. (2016). Antioxidant and antimutagenic activities of ripe bignay (Antidesma bunius) crude fruit extract. Philippine E-Ournal for Applied Research and Development, 6, 32-43.

Branco, I. G., Moraes, I. C. F., Argandoña, E. J. S., Madrona, G. S., dos Santos, C., Ruiz, A. L. T. G., Carvalho, J. E., \& Haminiuk, C. W. I. (2016). Influence of pasteurization on antioxidant and in vitro anti-proliferative effects of jambolan (Syzygium cumini (L.) Skeels) fruit pulp. Industrial Crops and Products, 89, 225-230. http://dx.doi. org/10.1016/j.indcrop.2016.04.055.

Butkhup, L., \& Samappito, S. (2008). Analysis of anthocyanin, flavonoids, and phenolic acids in tropical bignay berries. International Journal of Fruit Science, 8(1-2), 15-34. http://dx.doi. org/10.1080/15538360802365913.

Caleja, C., Barros, L., Antonio, A. L., Oliveira, M. B. P. P., \& Ferreira, I. C. F. R. (2017). A comparative study between natural and synthetic antioxidants: evaluation of their performance after incorporation into biscuits. Food Chemistry, 216, 342-346. http://dx.doi.org/10.1016/j. foodchem.2016.08.075. PMid:27596429.

Chaikham, P. (2015). Comparison of high hydrostatic pressure and thermal processing on physicochemical and antioxidant properties of maoberry (Antidesma thwaitesianum Müell. Arg.) juice. International Food Research Journal, 22(5), 1993-2001.
Chaikham, P., Prangthip, P., \& Seesuriyachan, P. (2016). Ultra-sonication effects on quality attributes of maoberry (Antidesma bunius L.) juice. Food Science and Technology Research, 22(5), 647-654. http://dx.doi. org/10.3136/fstr.22.647.

Fredes, C., Osorio, M. J., Parada, J., \& Robert, P. (2018). Stability and bioaccessibility of anthocyanins from maqui (Aristotelia chilensis [ Mol. ] Stuntz) juice microparticles. Lebensmittel-Wissenschaft + Technologie, 91, 549-556. http://dx.doi.org/10.1016/j.lwt.2018.01.090.

Jamal, P., Hashlamona, A., Jaswir, I., Akbar, I., \& Nawawi, W. M. F. (2017). Extraction of lycopene from tomato waste using solid state fermentation. International Food Research Journal, 25, 416-421.

Jiang, B., Mantri, N., Hu, Y., Lu, J., Jiang, W., \& Lu, H. (2015). Evaluation of bioactive compounds of black mulberry juice after thermal, microwave, ultrasonic processing, and storage at different temperatures. Food Science \& Technology International, 21(5), 392-399. http://dx.doi. org/10.1177/1082013214539153. PMid:24917651.

Jiang, D. Q., Guo, Y., Xu, D. H., Huang, Y. S., Yuan, K., \& Lv, Z. Q. (2013). Antioxidant and anti-fatigue effects of anthocyanins of mulberry juice purification (MJP) and mulberry marc purification (MMP) from different varieties mulberry fruit in China. Food and Chemical Toxicology, 59, 1-7. http://dx.doi.org/10.1016/j.fct.2013.05.023. PMid:23727333.

Jorjong, S., Butkhup, L., \& Samappito, S. (2015). Phytochemicals and antioxidant capacities of Mao-Luang (Antidesma bunius L.) cultivars from Northeastern Thailand. Food Chemistry, 181, 248-255. http:// dx.doi.org/10.1016/j.foodchem.2015.02.093. PMid:25794747.

Kamiloglu, S., Serali, O., Unal, N., \& Capanoglu, E. (2013a). Antioxidant activity and polyphenol composition of black mulberry (Morus nigra L.) products. Journal of Berry Research, 3(1), 41-51. http://dx.doi. org/10.3233/JBR-130045.

Kamiloglu, S., Serali, O., Unal, N., \& Capanoglu, E. (2013b). Antioxidant activity and polyphenol composition of black mulberry (Morus nigra L.) products. Journal of Berry Research, 3(1), 41-51. http://dx.doi. org/10.3233/JBR-130045.

Kenny, O., Smyth, T. J., Hewage, C. M., \& Brunton, N. P. (2013). Antioxidant properties and quantitative UPLC-MS analysis of phenolic compounds from extracts of fenugreek (Trigonella foenumgraecum) seeds and bitter melon (Momordica charantia) fruit. Food Chemistry, 141(4), 4295-4302. http://dx.doi.org/10.1016/j. foodchem.2013.07.016. PMid:23993618.

Khomdram, S., \& Devi, G. A. S. (2010). Determination of antioxidant activity and vitamin $\mathrm{C}$ of some wild fruits of Manipur. The Bioscan, 5(3), 501-504.

Kumar, Y., Yadav, D. N., Ahmad, T., \& Narsaiah, K. (2015). Recent trends in the use of natural antioxidants for meat and meat products. Comprehensive Reviews in Food Science and Food Safety, 14(6), 796812. http://dx.doi.org/10.1111/1541-4337.12156.

Li, X., Wu, X., \& Huang, L. (2009). Correlation between antioxidant activities and phenolic contents of radix Angelicae sinensis (Danggui). Molecules, 14(12), 5349-5361. http://dx.doi.org/10.3390/ molecules14125349. PMid:20032898.

Mercali, G. D., Schwartz, S., Marczak, L. D. F., Tessaro, I. C., \& Sastry, S. (2014). Ascorbic acid degradation and color changes in acerola pulp during ohmic heating: effect of electric field frequency. Journal of Food Engineering, 123, 1-7. http://dx.doi.org/10.1016/j. jfoodeng.2013.09.011.

Padilha, C., Miskinis, G. A., de Souza, M. E., Pereira, G. E., de Oliveira, D., Bordignon-Luiz, M. T., \& Lima, M. D. (2017). Rapid determination of flavonoids and phenolic acids in grape juices and wines by RP-HPLC/ DAD: method validation and characterization of commercial products of the new Brazilian varieties of grape. Food Chemistry, 228, 106-115. http://dx.doi.org/10.1016/j.foodchem.2017.01.137. PMid:28317702. 
Park, I. K., \& Kang, D. H. (2013). Effect of electropermeabilization by ohmic heating for inactivation of escherichia coli O157: H7, Salmonella enterica serovar typhimurium, and listeria monocytogenes in buffered peptone water and apple juice. Applied and Environmental Microbiology, 79(23), 7122-7129. http://dx.doi.org/10.1128/ AEM.01818-13. PMid:23995939.

Pisoschi, A. M., \& Negulescu, G. P. (2011). Methods for total antioxidant activity determination: a review. Biochemistry and Analytical Biochemistry, 1(1), 1-10. http://dx.doi.org/10.4172/2161-1009.1000106.

Prakash, D., Upadhyay, G., Pushpangadan, P., \& Gupta, C. (2011). Antioxidant and free radical scavenging activities of some fruits. Journal of Complementary \& Integrative Medicine, 8(1), 23. http:// dx.doi.org/10.2202/1553-3840.1513. PMid:22754941.

Samappito, S., \& Butkhup, L. (2008). An analysis on organic acids contents in ripe fruits of fifteen Mao Luang (Antidesma bunius) cultivars, harvested from dipterocarp forest of Phupan Valley in Northeast Thailand. Pakistan Journal of Biological Sciences, 11(7), 974-981. http://dx.doi.org/10.3923/pjbs.2008.974.981. PMid:18810965.

Sánchez-Moreno, C., Plaza, L., De Ancos, B., \& Cano, M. P. (2003). Quantitative bioactive compounds assessment and their relative contribution to the antioxidant capacity of commercial orange juices. Journal of the Science of Food and Agriculture, 83(5), 430-439. http://dx.doi.org/10.1002/jsfa.1392.

Sripakdee, T., Sriwicha, A., Jansam, N., Mahachai, R., \& Chanthai, S. (2015). Determination of total phenolics and ascorbic acid related to an antioxidant activity and thermal stability of the Mao fruit juice. International Food Research Journal, 22(2), 618-624.
Swami, S. B., Thakor, N. S. J., Patil, M. M., \& Haldankar, P. M. (2012). Jamun (Syzygium cumini (L.)): a review of its food and medicinal uses. Food and Nutrition Sciences, 3(8), 1100-1117. http://dx.doi. org/10.4236/fns.2012.38146.

Tezcan, F., Gultekin-Ozguven, M., Diken, T., Özçelik, B., \& Erim, F. B. (2009). Antioxidant activity and total phenolic, organic acid and sugar content in commercial pomegranate juices. Food Chemistry, 115(3), 873-877. http://dx.doi.org/10.1016/j. foodchem.2008.12.103.

Timmers, M. A., Guerrero-Medina, J. L., Esposito, D., Grace, M. H., Paredes-López, O., García-Saucedo, P. A., \& Lila, M. A. (2015). Characterization of phenolic compounds and antioxidant and anti-inflammatory activities from Mamuyo (Styrax ramirezii Greenm.) fruit. Journal of Agricultural and Food Chemistry, 63(48), 10459-10465. http://dx.doi.org/10.1021/acs.jafc.5b04781. PMid:26575200.

Wu, S., Dastmalchi, K., Long, C., \& Kennelly, E. J. (2012). Metabolite profiling of jaboticaba (Myrciaria cauliflora) and other dark-colored fruit juices. Journal of Agricultural and Food Chemistry, 60(30), 7513-7525. http://dx.doi.org/10.1021/ jf301888y. PMid:22809264.

Yildiz, H., Bozkurt, H., \& Icier, F. (2009). Ohmic and conventional heating of pomegranate juice: effects on rheology, color, and total phenolics. Food Science \& Technology International, 15(5), 503-512. http://dx.doi.org/10.1177/1082013209350352. 